\title{
Effect of financial performance on firms' value of cable companies in Indonesia
}

\author{
Irwan Mangara Harahapa ${ }^{a}$ Ivana Septiani ${ }^{a}$, and Endri Endri ${ }^{*}$
}

\begin{tabular}{l}
${ }^{a}$ Universitas Mercu Buana, Jakarta \\
\hline C H R O N I C L E \\
\hline Article history: \\
Received May 152020 \\
Received in revised format May \\
162020 \\
Accepted July 62020 \\
Available online \\
July 122020 \\
\hline Keywords: \\
Firm value \\
Financial performance \\
Price book value \\
Panel regression model
\end{tabular}

\section{A B S T R A C T}

\begin{abstract}
The study aims to analyze the effect of current ratio (CR), return on equity (ROE), net profit margin (NPM), total asset turnover (TATO) and debt to asset ratio (DAR) on firms' value. The sample of the research is the 4 cable sub-sector companies from the manufacturing industry which are listed on the Indonesia Stock Exchange (IDX) for the 2014-2018 period and they are analyzed using panel data regression method. Empirical findings of the study indicate that ROE had a negative influence on firm value, while NPM, TATO, and DAR had positive effects on firm value. However, the CR ratio had no effect on firm value. Taken together all financial performance variables affect the value of the company. The results of the study have implications that the value of the company can be improved if the company still maintains a balanced capital structure between debt and equity, provided that debt is used to finance assets that are productive and efficient so that they can generate profits.
\end{abstract}

C 2020 by the authors; licensee Growing Science, Canada

\section{Introduction}

The existence of a cable company in Indonesia plays an important role in supporting the country's infrastructure development program. However, fluctuations in prices of copper raw materials make companies engaged in the cable sector less profitable. This is a challenge for each investor in determining the best performance choices in cable companies, and how good performance can reflect the company's performance and the company's value that can affect the investor's decision (Endri, 2019). The company has a responsibility to maintain sustainability and growth to provide hope of profits to investors and the company can continue to exist in carrying out wheel activities in accordance with the wishes and investors can feel extraordinary profits. This is a priority for companies to maximize the value of the company that provides prosperity to investors. Increasing company value has an impact on the increase in the company's stock price, so that it will provide full welfare to shareholders and is shown in the increasing market value (Sugianto et al., 2020). This is in line with what was said by Sharif et al., (2015) who said that investment opportunities that affect market value based on rising share prices will shape the value of the company. This opportunity will illustrate the company's success due to positive future changes created by the company's success in increasing the value of its shares. According to Jatmiko (2015) to get Price to Book Value results there are several steps that can be used among other things: Price Earnings Ratio and Price / Cash Flow Ratio. The author will take the PBV variable as the dependent variable used as the value of the company because PBV has an important role that is used to measure stock prices and is used as a guide in determining the purchase of shares in shares to be bought and the ups and downs in the PBV ratio are equivalent to changes and fluctuations in the value of shares (Putra et al., 2007). In addition, PBV is used to compare the value of shares with the price of books while describing how valuable the market can value the value of an issuer's book. Price To Book Value embodies the capital invested in relationship with the value of the company. This means that if the shareholder value goes up due to the company, the higher Price To Book value is shown (Endri \& Fathony, 2020).

* Corresponding author. Tel.: +628129204067

E-mail address: endri@mercubuana.ac.id (E. Endri) 
Empirical studies conducted by Rinnaya et al., (2016) revealed partially showing that TATO as an activity ratio influences the value of the company, but related to the explanation of Liquidity revealed by Daeli and Endri (2018) that a high liquidity ratio actually reduces the value of the company since it is considered that the company has unused funds or is called idle funds. According to Hasibuan et al., (2016) DR had a positive and significant influence on the value of the company as well as ROE affecting the value of the company comparable to research conducted by Putri et al., (2016) which stated that ROE had a significant negative effect and Net Profit Margin has a positive effect on company value which means that if the value of ROE goes down, the value of the company will increase, if Return On Equity goes up, the value of the company will go down, this is in line with what Sari and Endri (2019) who said that ROE is influenced by 3 factors: Net Profit Margin, total asset turnover and debt ratio. This illustrates that the greater the use of debt in the company resulting in the growth of interest, the greater the impact on the level of profits obtained by investors, the greater the ROE the greater the use of debt results in and this brings a negative impact on price of investors. Meanwhile they added that there is a characteristic relationship between leverage ratios and profitability ratios where profitability is considered a major goal in the company and is considered important because the company can pay all its obligations from the results of profits, but on the other hand many companies use their debt to increase all activities used to get profits or its profitability. This is what drives researchers in measuring company value (PBV) as an independent or independent variable by using the ratio of Return On Equity, Net Profit Margin, Debt Ratio, Total Asset Turn Over, and Current Ratio as Dependent Variables. The following PBV data obtained from the Indonesia Stock Exchange in the 2014-2018 cable industry and its financial performance.

\section{Literature Review}

High Price to Book Value (PBV) illustrates that a company in prospects will experience progress going forward, this is what underlies the confidence of a market. And it is a priority for shareholders or investors because the rising PBV reflects the triumph of the owner of the company which is automatically felt by shareholders and other investors. Then the owner of the company in making decisions must pay attention to the results and returns that will be obtained as well as think about and predict everything that can produce profits. This is in line with what was conveyed by Putra et al., (2007) which stated that a good prospect is a company that is able to provide positive information in increasing the value of the company, so that the prospect of openness is clear in front of him and therefore Investors are willing to invest extra money because of expectations in the future. Company value illustrates the overall perception of the company so that if the company is sold then that value will be marketed and the value that can be bought by the buyer. As stated by Sugianto et al., (2020) the value of the company is the ability to be fulfilled by prospective buyers if the company will on sale. According to analysis Fathony et al., (2020), the value of the company can also be shown by the ups and downs of profitability generated by the company. Profitability is the ability of a company to generate profits for a certain period. Meanwhile according to Endri et al. (2019), the Profitability Ratio is all power that is managed both the elements of marketing products and investment management in generating profits. This ratio is also used as an evaluation tool for company performance to be better. What is revealed Brigham and Houstan (2006: 107), profitability is the end result of a number of company management policies and decisions, which is used as a tool in measuring the success of the company as well as evaluating the manager's performance. In this study, profitability which is used as a free variable is Return On Equity (ROE) and is the result of an increase in income available to the owners of the Company for the capital they invest in the company or the net profits obtained by Investors and Creditors. Shahnia et al. (2020), investors can predict the condition of a company to see the results of the investment in shares that it plants. If ROE goes up, the company will get better and we expect a better level of stock returns generated by shareholders. Thus, ROE will attract the attention of investors who have a positive impact on the value of the company. In addition, according to Rinaldo and Endri (2020), ROE is influenced by 3 factors, namely Net Profit Margin, Total assets turnover and debt ratio. The use of large debts in the company also causes a large interest which has an impact on the level of profits obtained by investors. This condition can be interpreted that the greater the ROE, the more companies use debt and this brings negative impacts for investors. Differently expressed by Dewi and Wirajaya (2013) which revealed that ROE had a significant positive effect on firm value which conducted research on Manufacturing companies in 2005-2007.

Meanwhile Leverage Ratio is a company's ability to measure all its activities using debt (Widyawati \& Endri, 2018) or how much the company's assets are financed by debt compared to own capital. Issuers that have a low leverage value will also have a low leverage risk. Debt Ratio (DR) that shows a large value will also lead to a risk that will be experienced by a company and cause the company's ability to pay its debts is doubtful, so that it can automatically lower the value of the company. This is supported by the results of research revealed by Daeli and Endri (2018) which revealed that DR had a negative effect on Company Value, but the existence of the Trade Off theory revealed that an increase in the debt ratio would increase the company's value of a tax rate multiplied by the amount of debt. Differently expressed by Vo and Ellis (2017) where they illustrated that debt policy had a significant positive effect on firm value. In line with what was expressed by Modigliani and Miller (1963) by adding an income tax element, the delivery of debt will increase the value of the Company. So, in reality not always a low DR guarantees to be safer than a high DR since sometimes debt is needed to carry out its business activities in 
achieving maximum profit. Conclusions drawn from the size of the DR can have a negative and positive effect on stock prices that reflect Company Value. Total Asset Turn Over is said to be in the prime condition of a company if it has a fast asset turnover in a certain period of time and is a sign for the market in attracting investors to join in investing their capital. According to Rinaldo and Endri (2020), the Total Assets Turnover Ratio measures the activity of the assets and the company's ability to generate sales through the use of these assets. In addition, according to Rusdana and Endri (2020) the Total Turnover Asset Ratio is a calculation of the overall turnover of assets used because of its broad scope, can be used in various types of businesses, this ratio can be described as the ability of the total asset turnover in obtaining sales. The greater and more active asset turnover occurs, the more effective the assets are used in the company's effectiveness. This can affect the price of shares that have a positive impact on the value of an increasing company. This correlation can be in line with the proof by Murtadlo et al. (2014) on the results of the study revealed that the significant turnover of fast and high total assets Turn Over will increase the value of the Company. This is in line with research conducted by Purnami and Artini (2016) which states that TATO has a significant positive effect on firm value (PBV), but it is different from what was stated by Stiyarini and Santoso (2016) which states that TATO has no effect on value the company. In contrast, a study conducted by Astutik (2017) revealed that TATO had a nonsignificant negative effect on Company Value. Liquidity illustrates the ability of a company to fulfill all financial obligations that must be paid. Companies with high liquidity or liquidity means that more dividends or cash flow are paid to shareholders. So, the greater the amount of cash available, the better the company's liquidity is illustrated and the greater the company's ability to pay dividends, this was revealed Zulkifili et al. (2017). Liquidity Ratios in this study use the Current Ratio. Meanwhile according to Firdaus and Endri (2020) Current Ratio also shows the level of security because it reflects the ability to process securities, receivables and inventories in the payment of current debts or illustrates the ability of issuers to fulfill their shortterm obligations at the time of payment using their current assets. Thus, the liquidity ratio is an indicator of the company's ability to be able to pay all its current debts if liquidity is low, reflecting a negative view of the company's ability, thereby affecting investor confidence as well as the Company's value. However, on one hand the high value of the current ratio can be a reflection that there is an excess of unemployed funds which indicates that the company's operations are running poorly so that it has a negative impact on the company and also on the value of the company this is in accordance with research from Endri and Fathony (2020), while Lumoly et al., (2018) based on the results of his research CR did not affect the value of the company (revealed such a thing for non-service sector companies while Rahmawati (2017) which revealed that CR had no negative effect on firm value. Then the next discussion is Net Profit Margin according to Firdaus and Endri (2020), Net Profit Margin is a ratio used to describe the empowerment of companies to obtain maximum net profit. Meanwhile according to Brigham \& Houston (2006) the existence of the Profit Margin is the result of the calculation of the profitability of the company resulting from sales by adding up the total cost and income tax. Thus, Net Profit Margin can describe a measure of the issuer's efficiency in generating profits by calculating interest and income taxes compared to the total value of the company. The greater this ratio, the better the company's performance. This is in line with research conducted by Irayanti and Tumbel (2014); Rompas (2013), which states that Net Profit Margin has a significant positive effect on Company Value, in contrast to those expressed by Shan (2015) who revealed that NPM had no effect on Company Value. With a variety of results obtained, the researcher will see the extent to which these ratios affect the Value of the Company.

\section{Methodology}

The current study examines the relationship of influence between ROE, DB, TATO, CR, NPM on the Value of Companies listed on the Indonesia Stock Exchange in the 2014-2018 Period. This research is included in the quantitative research with sampling technique Purposive sampling technique taken from 4 companies from a total of 6 companies listed on the Indonesia Stock Exchange for 5 years to get 20 data cable companies in the 2014-2018 period.

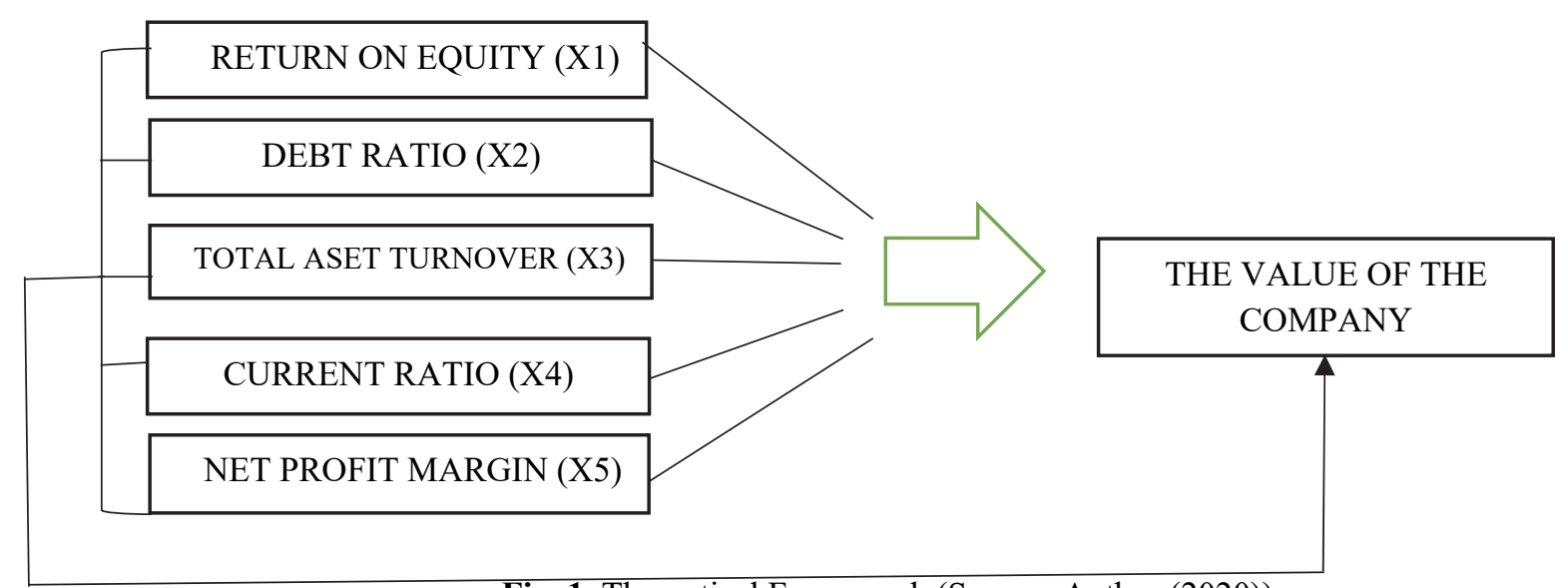

Fig. 1. Theoretical Framework (Source: Author (2020)) 
In this study the authors used Data Analysis with Panel Data Regression Method using Eviews 9. The equation of panel data model analysis used in the study is as follows:

$\mathrm{Y}($ Company Value $)=\mathrm{O}+\beta_{1} \mathrm{ROE}_{\mathrm{it}}+\beta_{2} \mathrm{DR}_{\mathrm{it}}+\beta_{3} \mathrm{TATO}_{\mathrm{it}}+\beta_{4} \mathrm{CR}_{\mathrm{it}}+\beta_{5} \mathrm{NPM}_{\mathrm{it}}+\mathrm{e}$

where $e$ is the residual term, $\mathrm{i}=1,2,3,20 \mathrm{~N}=$ the amount of data the company processed and $\mathrm{t}=1,2,3,4,5$ years. All tests are carried out with the help of EViews9 statistics.

\section{Results and Discussion}

\subsection{Descriptive Statistic}

Descriptive statistical results the amount of data, minimum size, maximum size, middle size (median), average size (mean) and standard deviation of each variable. Descriptive statistical test results are shown in Table 1 as follows:

Table 1

Descriptive Statistic

\begin{tabular}{lllllll}
\hline & PBV & ROE & DAR & TATO & CR & NPM \\
\hline Mean & 0.981500 & 0.128000 & 1.659000 & 1.422500 & 1.698000 & 0.045500 \\
Median & 0.765000 & 0.115000 & 1.020000 & 1.415000 & 1.435000 & 0.040000 \\
Maximum & 2.920000 & 0.280000 & 7.400000 & 2.240000 & 3.410000 & 0.120000 \\
Minimum & 0.420000 & 0.010000 & 0.370000 & 0.960000 & 1.030000 & 0.000000 \\
Std. Dev. & 0.632266 & 0.077296 & 1.784963 & 0.331613 & 0.758465 & 0.030171 \\
Observations & 20 & 20 & 20 & 20 & & 20 \\
\hline Source: Data processed (2020 & & & & &
\end{tabular}

Based on the results of descriptive statistical tests that have been presented in Table 1, an overview of the dependent and independent variables can be seen as follows:

1) Observations or $\mathrm{N}$ are 20, indicating the data in sampling amounted to 20 data processed, which consists of 4 companies with a sample period of 5 years and consists of variable company value (PBV), ROE, DR, TATO, CR and NPM.

2) PBV value has a mean company of 0.981500 median of 0.765000 , the highest value of 2.9 .2 million achieved by PT Jembo Cable Company Tbk (JECC) in 2014, the lowest company value of 0.420000 achieved by PT Kabelindo Murni Tbk (KBLM) in 2018, and the standard Deviation worth 0.632266, shows a number greater than the average value of the company, with the size of the data deviation shows the high fluctuation of company value data.

3) Profitability which is represented by Ratio On Equity (ROE), has a mean ROE of 0.128000. This shows that almost all issuers in the sample could reap the net benefits obtained from managing their own capital as well as profits from the owner of investors valued at 0.128000 , with a median of 0.115000 , while achieving the highest maximum value of 0.280000 was achieved by PT Supreme Cable Manufacturing \& Commerce Tbk (SCCO) during 2016 and PT Jemblo Cable Company (JECC) in 2016, but in 2017 the lowest ROE value of 0.010000 was achieved by PT Supreme Cable Manufacturing \& Commerce Tbk (SCCO), and the standard deviation of 0.077296, smaller than the average value, with the small size of the data deviation shows the low fluctuation of Roe during the observation period.

4) Leverage represented by Debt to Asset Ratio (DR) has a mean DR of 1.659000. Stating that most samples show the relationship between the amount of long-term debt with the amount of capital owned by the company worth 1.659000 , the median of 1.020000, the highest value of 7.400000 achieved by PT Jemblo Cable Company (JECC) in 2014, while the lowest value of 0.370000 was achieved by Kabelindo Murni Tbk (KBLM) in 2018, and the standard deviation of 1.784963, is greater than the average value, with the large data deviation shows the high fluctuation of the DR of the Company's value data.

5) The Activity Ratio represented in this study with Total Assset Turnover (TATO) has a mean TATO of 1.422500. Stating that most sample issuers were able to use their total assets effectively to generate sales of 1.422500, meidan of 1.415000, the highest value of 2.240000 achieved by PT Supreme Manufacturing \& Commerce Tbk (SCCO) in 2014, while the lowest TATO value of 0.960000 was obtained PT Kabelindo Murni Tbk in 2018, and a standard deviation of 0.331613, smaller than the average value, with the small data deviation, showing low TATO fluctuations during the observation period.

6) While for Liquidity represented by the current ratio (CR) has a mean CR of 1.698000, a median of 1.435000, the highest value of 3.410000 achieved by KMI Wire and Cable Tbk (KBLMI) in 2016, while the lowest CR value of 1.030000 was achieved by PT. The Jemblo Cable Company (JECC) in 2014, and the standard deviation of 0.758465 , compared to the average value, showed a smaller size, with small data deviations, showing low CR fluctuations during the observation period.

7) While representing the independent profitability variable is the Net Profit Margin (NPM) with a mean NPM of 0.045500 , a median of 0.040000 , the highest value of 0.120000 achieved by PT KMI Wire and Cable Tbk (KBLI) in 2016, while the lowest value is 0.000000 achieved by PT Jemblo Cable Company (JECC) in 2015, and a standard deviation of 0.030171, which is smaller than the average value, with small data deviations showing low NPM fluctuations during the observation period. 
To calculate the existence of an influential relationship between the variables ROE, DR, TATO, CR and NPM on Company Value, we perform a regression analysis and the results are given in Table 2 as follows.

Table 2

Panel Data Equation

\begin{tabular}{|c|c|c|c|c|c|c|c|c|}
\hline \multirow{2}{*}{ Variable } & \multicolumn{4}{|c|}{ Model Commont Effect } & \multicolumn{4}{|c|}{ Model Fixedt Effect } \\
\hline & Coefficient & Std. Error & t-Statistic & Prob. & Coefficient & Std. Error & $\mathrm{t}$-Statistic & Prob. \\
\hline $\mathrm{C}$ & -0.378495 & 0.372702 & -1.015542 & 0.3271 & 0.188668 & 0.566897 & 0.332807 & 0.7455 \\
\hline ROE & -5.065669 & 1.958162 & -2.586951 & 0.0215 & -5.70527 & 2.449021 & -2.329612 & 0.0399 \\
\hline DAR & 0.390889 & 0.04676 & 8.359433 & 0 & 0.332942 & 0.0566 & 5.882356 & 0.0001 \\
\hline TATO & 0.678827 & 0.275359 & 2.46525 & 0.0272 & 0.565263 & 0.350167 & 1.614266 & 0.1348 \\
\hline CR & -0.192354 & 0.13148 & -1.46299 & 0.1656 & -0.277369 & 0.194912 & -1.42305 & 0.1825 \\
\hline NPM & 15.844 & 6.09266 & 2.600506 & 0.021 & 14.01412 & 7.58159 & 1.848441 & 0.0916 \\
\hline R-squared & 0.872941 & & & & 0.921194 & & & \\
\hline Adjusted R-squared & 0.827563 & & & & 0.86388 & & & \\
\hline F-statistic & 19.237 & & & & 16.07283 & & & \\
\hline $\operatorname{Prob}($ F-statistic) & 0.000008 & & & & 0.000048 & & & \\
\hline
\end{tabular}

Based on the results of the output in Table 3 it can be concluded that the variables ROE, DR, TATO and NPM affect the value of the company (PBV). This can be seen from the ROE Probability value of $0.0215<0.05$, DR probability value $0.0000<0.05$, TATO probability value of $0.0272<0.05$ and NPM probability value of $0.0210<0.05$. While the CR variable does not affect the value of the company (PBV). This can be seen from the CR probability value of $0.1656>0.05$. Then the F-statistical probability value is 0.000008 , the R-Square coefficient is 0.872941 or $87.294 \%$ and the Adjust R-Squares is 0.827563 , while in the Fixed Effect it is concluded that the variable ROE and DR affect the value of the company (PBV). This can be seen from the ROE probability value of $0.0399<0.05$ and the DR probability value of $0.0001<0.05$. Whereas the TATO, CR and NPM variables did not affect the value of the company (PBV). This can be seen from the TATO probability value of $0.1348>0.05$, CR probability value of $1,825>0.05$ and NPM probability value of $0.0916>0.05$. Then the F-statistical probability value is 16.07283, the R-Square coefficient is 0.921194 or 92.11945 AND the R-Square adjust is 0.863880 . In testing the model that must be determined by the researcher, the steps taken are processing panel data, namely:

- Chow Test. Chow Test is a form of testing used in determining the next step or to estimate panel data whether with a common effect model (CE) or a Fixed Effect (FE).

The hypothesis in the Chow Test is as follows: $\mathrm{H}_{0}$ : Select PLS (Common Effect Model) $\mathrm{H}_{1}$ : Select FE (Fixed Effect Model)

Table 3

Chow Test

\begin{tabular}{|c|c|c|c|}
\hline Effects Test & Statistic & d.f. & Prob. \\
\hline Cross-section F & 2.245078 & $(3,11)$ & 0.1401 \\
\hline Cross-section Chi-square & 9.553161 & 3 & 0.0228 \\
\hline
\end{tabular}

Source: Data Processed (2020).

Redundant Fixed Effects Tests Test cross-section fixed effects

From the data above shows that the Cross-section F probability value is greater than $\alpha(5 \%)$ which is $0.1401>0.05$, so $\mathrm{H} 0$ is accepted, which means Fixed effect is not a suitable method, so the method suitable for the model is the common effect model. Because the results of the Chow $\mathrm{H} 0$ test is accepted, then the thirsty test is no longer needed in determining and choosing a model between fixed effects or random effects, and the Lagrange multiplier (LM) test to compare random effects or common effects. Determinant Coefficient Test (R2) illustrates the ability of a model to explain the variation of the dependent variable. The coefficient of determination in this study was used to determine the effect of independent variables namely ROE, DAR, TATO, CR, and NPM affect the Dependent variable that is the company value as much as $82.7563 \%$ while the remaining $17.243 \%$ is contributed by the influence of other variables not included in this study

\subsection{Discussion}

\section{Effect of ROE on Company Value}

ROE has a negative influence on the value of the cable industry sector in the Indonesia Stock Exchange in 2014-2018. If ROE shows a high value, the company value will go down and vice versa because it is known that ROE has a negative direction and partially Return On Equity has a significant negative effect, this also means that the ROE conditional is influenced by 3 factors, namely net profit margin, Tattoos and debt ratio if ROE shows high values, it can be said that companies are considered to use a lot of debt so that it also has a negative impact on investors this is contrary to the results of research revealed by Endri et al., (2019) that ROE has a positive effect on stock prices and affects the value of the company in manufacturing companies in 
Bangladesh (Dey et al., 2018). However research conducted by Putri et al., (2016) on the industrial sector in BEI revealed that ROE has a significantly negative effect on the value of the company, Pangestu and Aji (2012) in contrast to that expressed by Endri and Fathony (2020) stating that ROE is not significantly influence the value of the company, and Nurhayati (2013) also says the same thing that ROE does not significantly influence the value of stock returns which means that the ability of a company to return stock returns is very influential on the amount of ROE value.

\section{Effect of DAR on Company Value}

The value of the obtained in the Debt ratio indicates that it has a positive effect. The higher the value of DAR, the higher the value of the company will be according to what was revealed by Hasibuan et al. (2016). This illustrates that the use of funds from outside companies whose companies are sampled are very small to finance the operations of their companies, therefore the use of small funds can get maximum profit. In addition, the use of sufficient and not too large funds obtained from investors can keep away from high risks in a company. Modigliani \& Miller's theory which says if the company's management uses debt close to $100 \%$ then the value of the company will crawl to the maximum. It is predicted that more and more use of debt will illustrate that there is a hope for an investor to see that the company will be able to develop capital and develop the company which will ultimately benefit investors and investors assume there is a hope that the company's value will be maximal and the value of the company will increase in line with the research disclosed by Vo and Ellis (2017) and Iqbal (2016); but found different things from research conducted by Natalia (2013). DR has no effect on company value and DR has a negative effect expressed by Rompas (2103) which states that if Dar is high then the value of the company decreases, the more debt company, the heavier the company will bear the operational costs and the cost of capital this will lead to low corporate value, Chowdhury and Chowdhury (2010) state that DAR has no effect on ROE which is the basis in assessing an investor can invest capital so that it affects the company's results.

\section{The effect of TATO on Company Value}

The value obtained from the TATO contribution has a positive effect on the firm's value. This indicates that the occurrence of high asset turnover causes the value of the company to increase. Companies are said to be efficient if they are able to manage assets to generate profits from sales and provide profits to the company (Rinnaya et al., 2016) where high total asset management can increase value to the company (Purnami \& Artini, 2016); Medy \& Chabachip 2017); who revealed the company's ability to manage earnings and sales results. but this is different from the research conducted by Andansari et al. (2016) which states that TATO has no influence on the value of the company

\section{Effect of CR on Company Value}

From the results of research on the Current Ratio, it is revealed that if a company has good liquid capability it does not make a reference in describing the value of the company increases. This can be caused by a lack of initial inventory funds to pay off debt and if this high liquidity ratio does not guarantee the company is in a good situation it means money not used, properly. This is in line with the research proposed by Endri and Fathony (2020) that the Current Ratio does not significantly influence the value of the company, Yusuf and Surjaatmadja (2018) which states that CR has no effect on Profitability which is the profit of the company, which in turn increases the Company's Value. But different things stated that CR has a positive effect on company value which means that company liquidity can be used well on sales results (Gladys \& Omagwa, 2017; Nainggolan \& Pratiwi, 2017), and negatively affect the value of the company obtained by Octav et al. (2015).

\section{The Effect of NPM on Company Value}

Net Profit margin illustrates the empowerment of companies to reduce operational expenses so that they can be efficient in a certain period of time. Then it indicates that the low value of the company is caused by the existence of a low Net Profit margin otherwise if the net profit margin is high it will also increase the value of the Company. Significant Positive Influences were also stated by Firdaus and Endri (2020) and Rompas (2013), while significant negative results were found by Asmiranto and Elif (2015) that NPM partially has a negative effect on the value of shares which is the value of the company, and the results of NPM have no effect on the value of the company disclosed (Sha, 2017).

\section{Conclusions}

The research obtained conclusions simultaneously drawn that the Variable Return On Equity, Debt Ratio, Total Asset Turn Over, Current Ratio and Net Profit Margin affect the Value of Companies engaged in the Cable Industry in the Indonesia Stock Exchange in 2014-2018, with the coefficient of determination seen that adjusted R-Squared value of 0.827563 or $82.7563 \%$. This shows that the five independent variables ROE, DR, TATO, CR and NPM affect the variable value of the company by $82.7563 \%$ while the remaining $17.243 \%$ is the contribution or influence of other variables not included in this study. Then this study partially revealed from the calculation that ROE had a significant negative effect on the value of companies in the Cable Industry that were listed on the Indonesia Stock Exchange in 2014-2018. This shows that the ROE is large because the company still uses debt in its profit acquisition, while the Debt Ratio has a significant positive effect on the Cable Industry Company 
Value of 2014-2018 on the IDX, the Debt Ratio illustrates the increasing PBV based on the use and management of debt both in sales and production activities. It also illustrates that there is still less use of debt compared to assets in the management of the company. So that the risk is getting smaller and increasing the value of the company, Total Assets Turn Over illustrates efficiency in the company. the more numbers show an increase in total asset turnover, the value of the company will experience a significant increase. In accordance with the results of research that shows TATO significant positive effect on the value of companies engaged in the Cable Industry in the period 2014-2018. It also illustrates how much rupiah in TATO is ultimately used in the sales process. Current Ratio does not affect the Value of Companies listed on the Indonesia Stock Exchange in 20142018. This is because there are funds that are unemployed and unused less well managed, so it has no effect in generating profits that ultimately on the Company Value. In this research, the results show that the Net Profit Margin has a significant positive effect on the Value of Companies listed on the Indonesia Stock Exchange in the Cable Industry sector in 2014-2018. This indicates that a high Net Profit Margin means that the company is able to increase its profit by reducing costs which impact on increasing the Company's Value. In the results of this study found the results of ROE Negative effect on Company Value. It is expected that the Company in using debt in its capital to be more effective in increasing profits so as to boost the value of the company. In addition, this is used as a suggestion for Investors to pay attention to this matter because ROE can affect changes in stock prices which in turn will affect Company Value. Furthermore, for the next research, it is not only to take the variables from the Cable Industry but to try other industries so that they can be compared with other industries, because of the different types of businesses, the behavioral characteristics taken are also different. And researchers can add other variables that are not measured in this study so that the results obtained can be more complete.

\section{References}

Andansari, N.A., Raharjo, K., \& Andiri, R. (2016). Pengaruh Return On Equity (ROE), Proce Earning Ratio (PER), Total Aset Turn Over (TATO) Dan Price To Book Value (PBV) Terhadap Return Saham (Studi kasus pada perusahaan Manufactur Sektor Makanan dan Minuman Yang terdaftar di BEI Periode 2008-2014). Journal of Accounting, 2(2), 1-10

Astutik, D. (2017). Pengaruh Aktivitas Rasio Keuangan terhadap Nilai perusahaan (Studi Pada Industri Manufaktur), Jurnal STIE Semarang, 9(1), 32-49.

Asmiranto, E., \& dan Elif, Y. (2015). Pengaruh Deviden Per Sahre (DPS), Dividen Payout Ratio (DPR), Price To Book Value (PBV), Debt To Equity Ratio (DER), Net Profit Margin (NPM), Dan Retun On Asset (ROA) terhadap harga saham pada Perusahaan Manufacturing Sub Sector Makanan dan Minuman Dalam Kemasan yang Terdaftar di BEI. Jurnal Ilmiah akuntansi Fakultas Ekonomi, 1(2),95-117.

Brigham, E. F., \& Houston, J.F. (2006). Dasar-Dasar Manajemen Keuangan. Penerjemah: Ali Akbar Yulianto. Edisi 10. Buku 1. Jakarta: Salemba Empat.

Chowdhury, A., \& Chowdhury, S. P. (2010). Impact of capital structure on firm's value: Evidence from Bangladesh. Business \& Economic Horizons, 3(3), 111-122.

Daeli, C., \& Endri. (2018). Determinants of firm value: A case study of cigarette companies listed on the Indonesia stock exchange. International Journal of Managerial Studies and Research(IJMSR), 6(8), 51-59.

Dey, R.K., Hossain, S.Z., \& Rahman, R.A. (2018). Effect of corporate financial leverage on financial performance: A study on publicity traded manufacturing company in Bangladesh. Asia School Science, 14(12), 124-133.

Dewi, A. S.M., \& Wirajaya, A. (2013). Pengaruh Struktur Modal, Profitabilitas dan Ukuran Perusahaan Pada Nilai Perusahaan, E Jurnal AKuntansi Universitas Udayana, 4(2), 358-372.

Endri, E., Dermawan. D., Abidin. Z., Riyanto. S. (2019). Effect of financial performance on stock return: Evidence from the food and beverages sector. International Journal of Innovation, Creativity and Change, 9(10), 335-350.

Endri. (2019). Determinant of firm's value: Evidence of manufacturing sectors listed in Indonesia Shariah Stock Index. International Journal of Recent Technology and Engineering (IJRTE), 8(3), 3995-3999.

Endri, E \& Fathony, M. (2020). Determinants of firm's value: Evidence from financial industry. Management Science Letters, 10(1), 111120. doi: $10.5267 /$ j.msl.2019.8.011.

Fathony, M., Khaq, A., \& Endri, E. (2020). The effect of corporate social responsibility and financial performance on stock returns. International Journal of Innovation, Creativity and Change, 13(1), 240-252.

Firdaus, F., \& Endri, E. (2020). Financial statement analysis: Evidence from Indonesian Bank BUKU IV. International Journal of Innovative Science and Research Technology, 5(4),455-461.

Gladys, M., \& Omagwa, J. (2017). Asset structure and financial performance: A case of the Nairobi securities exchange, Kenya. Research Journal of Finance and Accounting, 8(4), 192-200.

Hasibuan, V., Dzulkirom, M.A.R., \& Endang, N.G.W. (2016), Pengaruh Leverage Dan Profitabilitas Terhadap Nilai Perusahaan (Studi pada Perusahaan Prpperty dan Real Estate yang terdaftar Di Bursa Efek Indonesia Tahun 2012-2015). Jurnal Administrasi Bisnis (JAB), 39(1), $139-147$

Iqbal, M. (2016), Effect of liquidityand capital structure on financial performance: Evidence form banking sector. International Journal for Innovative Research in Multidisciplinary Field, 2(7), 1-9

Irayanti, D., \& Tumbel, A. I. (2014). Analisis Kinerja Keuangan Pengaruhnya terhadap Nilai Perusahaan pada Industri makanan dan minuman di BEI. Jurnal EMBA, 2(3),1473-1482.

Jatmiko, D.P. (2015). The relationship between return, price to earnings ratio, price to book value ratio, size and beta in different data period. Investment Management and Financial Innovations, 12(1), 47-59.

Lumoly, S., Murni, S., \& Untu, V.N. (2018). Pengaruh Likuiditas Ukuran Perusahaan Dan Profitabilitas Terhadap Nilai Perusahaan (Studi pada Perusahaan Logam dan Sejenisnya yang terdaftar di Bursa Efek Indonesia), Jurnal EMBA, 6(3), 1108-1117. 
Medy, M., \& Chabachib, M. (2017). Analisis Pengaruh DER CR dan TATO terhadap PBV dengan ROA sebagai Variabel Intervening (Studi pada Perusahaan Property dan Real Estate yang terdaftar Pada BEI Tahun 2011-2014). Diponegoro Journal of Management, 6(1), 1-13.

Modigliani, F., \& Miller, M. H. (1963). Corporate income taxes and the Cost of Capital: A correction. The American Economic Review, 53(3), 433-443.

Murtadlo, A.A., Imam, Y., \& Wahono, B. (2014), Effect of capital structure, wealth structure and asset turnover on financial performance (case study in real estate companies listed on the IDX). JEMA, 12(1), 1-10

Nainggolan, H.L., \& Pratiwi, P.S. (2017). Analysis of factors affecting corporate financial performance. Media Economics and Management, $32(1), 80-96$

Nurhayati, M. (2013). Profitability, liquidity, and company size influence on dividend policy and corporate value of non service sector. Journal of Finance and Business, 5(2), 145-153.

Natalia, O.M. (2013). Leverage Pengaruhnya Terhadap Nilai Perusahaan Pada Industri Manufaktur Yang Go Public Di Indonesia. Jurnal EMBA 1(3), 81-89.

Octav, A., Akhmad, T., \& Ika, S. (2015). Pengaruh Kinerja Keuangan Terhadap Nilai Perusahaan di Perusahaan Industry Makanan dan Minuman yang Terdaftar di Bursa Efek Indonesia. E SOSPOL, 2(1), 7-11.

Putra, T.P., Chabachib,M., Haryanto, M., \& Pangestuti, I.R.D., (2007). Pengaruh Kinerja Keuangan dan Beta Saham Terhadap Price to Book Value (Studi Kasus pada Perusahaan Real Estate dan Property yang Listed di Bursa Efek Indonesia Periode Tahun 2004-2006). Jurnal Studi Manajemen dan Organisasi, 4(2), 81-90.

Putri, R.H., Zahroh,Z.H., Endang, N.P. (2016), Pengaruh Rasio Likuiditas \& Rasio Profitabilitas Terhadap Nilai Perusahaan, Jurnal Administrasi Bisnis (JAB), 38(2),38-45

Pangestuti, I.R.D., \& Aji, M.N. (2012). Analisis faktor-faktor Yang Mempengaruhi Price Earning Ratio (Studi empiris pada Perusahaan Manufactur yang terdaftar di BEI 2007-2010). Journal Of Mangement, 1(1),382-391

Purnami, K.D.A., \& Artini, L.G.S. (2016). Pengaruh Investment Opportunity Set, Total Asset Turn Over, dan Sales Growth Terhadap Kebijakan Dividen. Jurnal Manajemen Unud, 5(2), 1309-1337.

Rahmawati, A. (2017). Kinerja Keuangan dan Tingkat Pengembalian Saham: Studi Pada Perusahaan Asuransi Di Bursa Efek Indonesia. Esensi: Jurnal Bisnis dan Manajemen,7(1),1-14.

Rinaldo, N. E., \& Endri, E. (2020). Analysis of financial performance of plantation subsector companies listed on the Indonesia Stock Exchange for the 2014-2019 Period. International Journal of Innovative Science and Research Technology, 5(4),530-537

Rinnaya, I.Y., Andini, R., \& Oemar, A. (2016). Pengaruh Profitabilitas, Rasio Aktivitas, Kepuusan Pendanaan, Keputusan Investasi Terhadap Nilai Perusahaan (Studi Empiris pada Perusahaan Manufaktur yang terdaftar di BEI Tahun 2010-2014), Jurnal Of Accounting 2(2),1-18.

Rusdana, R. \& Endri, E. (2020). Analysis of Financial Performance Tobacco Listed in Indonesia Stock Exchange. JKBM (JURNAL KONSEP BISNIS DAN MANAJEMEN), 6(2), 179-187.

Rompas, G.P. (2013). Likuiditas Solvabilitas dan Rentabilitas terhadap Nilai Perusahaan BUMN yang terdaftar di Bursa Efek Indonesia. Jurnal EMBA, 1(3), 252-262.

Putri, R.H., Zahroh, Z.A., \& Endang, M.G.W. (2016). Pengaruh Rasio Likuiditas \& Rasio Profitabilitas Terhadap Nilai Perusahaan. Jurnal Administrasi Bisnis (JAB), 38(2), 38-45

Sari, F. N., \& Endri, E. (2019). Determinants of Return on Assets (ROA) On Conventional Banks Listed On Indonesian Stock Exchange (IDX) Period 2013 - 2017, IOSR Journal of Business and Management (IOSR-JBM), 21(4. Ser. II): 52-62. DOI: 10.9790/487X2104025262

Shahnia, C., Purnamasari, E.D., Hakim, L., \& Endri, E. (2020). Determinant of profitability: Evidence from trading, service and investment companies in Indonesia. Accounting, 6(5), 787-794. doi: 10.5267/j.ac.2020.6.004

Sharif, T., Purohit, H., \& Pillai, R. (2015). Analysis of Factors Affecting Share Prices: The Case of Bahrain Stock Exchange. International Journal of Economics and Finance, 7(3), 207-216. doi:10.5539/ijef.v7n3p207.

Sugianto, S., Oemar, F., Hakim, L., \& Endri, E (2020). Determinants of Firm Value in the Banking Sector: Random Effects Model. International Journal of Innovation, Creativity and Change, 12(8), 208-21.

Stiyarini., \& Santoso, B.H. (2016). Pengaruh Kinerja Keuangan Terhadap Nilai Perusahaan Pada Perusahaan Jasa Telekominikasi. Jurnal Ilmu dan Riset Manajemen,5(2), 1-21

Sha, T. L. (2017). Pengaruh Kebijakan Dividen, Likuiditas, Net Profit Margin, Return On Equity, Dan Price To Book Value Terhadap Harga Saham Pada Perusahaan Manufaktur Yang Terdaftar Di Bursa Efek Indonesia 2010 - 2013. Jurnal Akuntansi, $19(2), 276$. https://doi.org/10.24912/ja.v19i2.99

Vo, X. V., \& Ellis, C. (2017). An empirical investigation of capital structure and firm value in Vietnam. Finance Research Letters, 22, 9094. https://doi.org/10.1016/j.frl.2016.10.014

Widyawati, A., \& Endri. (2018). Determinant The capital structure of the Coal Mining Company Listed on the Indonesia Stock Exchange. Scholars Journal of Economics, Business and Management, 5(8), 799-807.

Yusuf, M., \& Surjaatmadja, S. (2018), Analysis of financial performance on profitability with non performance financing as variable moderation. International Journal of Economics and Financial Issues, 8(4), 126-132

Zulkifili, Endri, \& Kurniasih, A. (2017). Determinan Internal Dividend Payout Ratio Peerusahaan Farmasi Tedaftar di Bursa Efek Indonesia. Jurnal Keuangan dan Perbankan, 21(2), 238-252.

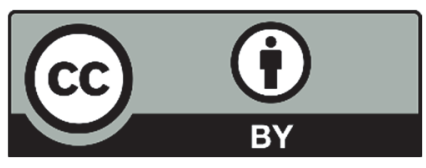

(C) 2020 by the authors; licensee Growing Science, Canada. This is an open access article distributed under the terms and conditions of the Creative Commons Attribution (CC-BY) license (http://creativecommons.org/licenses/by/4.0/). 